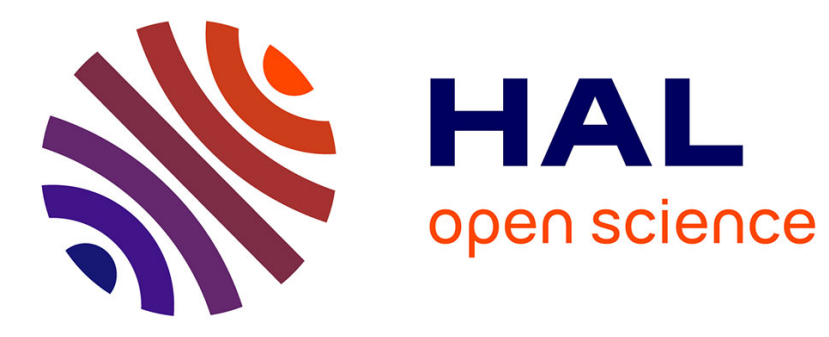

\title{
Rural Banditry in Colonial Algeria (1871-1914)
}

Antonin Plarier

\section{To cite this version:}

Antonin Plarier. Rural Banditry in Colonial Algeria (1871-1914). Crime, Poverty and Survival in the Middle East and North Africa, I.B. Tauris, 2019, 10.5040/9781838605902.ch-007 . hal-03449900

\section{HAL Id: hal-03449900 https://hal.science/hal-03449900}

Submitted on 25 Nov 2021

HAL is a multi-disciplinary open access archive for the deposit and dissemination of scientific research documents, whether they are published or not. The documents may come from teaching and research institutions in France or abroad, or from public or private research centers.
L'archive ouverte pluridisciplinaire HAL, est destinée au dépôt et à la diffusion de documents scientifiques de niveau recherche, publiés ou non, émanant des établissements d'enseignement et de recherche français ou étrangers, des laboratoires publics ou privés. 


\title{
Rural Banditry in Colonial Algeria (1871-1914)
}

\author{
Antonin Plarier
}

Banditry in Algeria was an object of fear and fascination among the French colonial population and the subject of a considerable volume of written commentaries. The colonial authorities sought to impress the significance of the problem upon the public. In 1892 the General Council of Algiers confidently estimated the number of bandits roaming the country at $1,300 .{ }^{1}$ Meanwhile, newspapers and the administration relayed the message, already circulating as a rumour, that 900 Algerians sentenced to forced labour in French Guiana had escaped and returned to Algeria. ${ }^{2}$ The bandits' possible transformation into a menacing army was the stuff of nightmares for the European colonists. This fear led them to exaggerate the severity of the phenomenon of banditry. ${ }^{3}$ The figures put forward by the General Council of Algiers may have been fanciful, yet Arezky el Bashir's band of thirty-five individuals, which enjoyed a large support base in the rural regions, was not to be underestimated. ${ }^{4}$

The social phenomenon of banditry was present throughout Algeria's colonial history. Scholars of the Maghreb and the Middle East have used and debated the theoretical model of the social bandit derived originally from the work of Eric Hobsbawm. ${ }^{5}$ Historian Jean Déjeux has readily applied the concept of social banditry to Algeria, ${ }^{6}$ whereas David Hart has criticized its use, arguing that it relies too heavily on the imagery of bandits found in folklore. ${ }^{7}$ Alain Mahé, using the term 'bandits of honor', argues that bandits endorsed the 'cardinal values of virility and honor' and were therefore early champions of the values defended by the National Liberation Army. ${ }^{8} \mathrm{He}$ thus endorses Mahfoud Kaddache's thesis that bandits of honour were Algeria's first 'patriots' ${ }^{9}$ His thesis subsuming the history of colonial social conflict within a narrative of the development of the national movement is, however, potentially reductive and demands interrogation. ${ }^{10}$ This chapter aims to shed new light on the phenomenon of banditry in rural societies transformed by colonization.

The colonial conquest of Algeria in 1830 triggered a vast movement of expropriation that eventually affected the whole country. From 1830 to 1870 , hundreds of thousands of hectares of land were transferred from their Algerian owners to the hands of the

I wish to thank Joseph La Hausse de Lalouvière (Harvard University) for his careful reading and constructive criticism. 
settlers, colonial companies or the state. The Europeans appropriated land through various means, including sequestration, the ordinances of 1844 and 1846, and the senatus-consulte of $1863 .{ }^{11}$ This process reached its peak in 1871 when the colonial administration oversaw a massive sequestration in response to an insurrection.. ${ }^{12}$

The multifaceted process of dispossession offers a gateway to understanding banditry. The term 'banditry' needs to be carefully defined, however, since the colonial administration used it not only to describe but also to denigrate. Not relying on the colonial authorities' definition, this chapter returns to Hobsbawm's original concept of the bandit as a member of 'a group that uses violence and practices armed robbery', one who acts outside the law and is pursued by its enforcers. ${ }^{13}$ The bandit's resilience depends on their connection to the rural environment from which they emerged.

\section{The conditions for the emergence of banditry}

The insurrection of 1871 led by El Moqrani spread across a third of Algeria's territory. ${ }^{14}$ The suppression of this movement prompted the adoption of a broad policy of economic sanctions. The authorities imposed collective fines on the insurgents and carried out individual and collective sequestrations of the insurgents' land. Some of the land sequestrated collectively could be bought back by its owners at one-fifth of its value. ${ }^{15}$ However, the authorities prevented the repurchase of lands deemed important for colonization. Former owners were permitted to occupy those lands until the colonial administration had sufficient means to allocate them to settlers, usually within the framework of settlement villages. These sequestrations restarted the official process of settlement which turned over 643,546 hectares of land to settlement villages. ${ }^{16}$ More than a third of this land (36.9 per cent, 234,375 hectares) came from the sequestrations of $1871 .{ }^{17}$ The act of sequestration preceded, often by several years, the eventual foreclosure on the properties and eviction of their original owners. The settlement village of Yakouren in Kabylia was only opened in 1888, several years after the creation of the neighbouring villages of Fréha and Mekla and seventeen years after the sequestration was announced. The Yakouren settlement was based on 408 hectares of seized land plus a nearby cork oak forest that was incorporated into the colonial domaine, as explained below. All of the land allocated to this village came from the sequestration of 1871 . The state's land grab policy contributed to the rise of banditry, and it is striking how much the two processes went hand in hand. Arezky el Bachir's band appears to have sprung up when the settlement process was at its most intensive at the time when Yakouren was created - and grew in numbers until the beginning of 1894, when the majority of its members were either eliminated or arrested during a major military campaign. ${ }^{18}$

Land dispossession was accompanied by increasing restrictions on customary rights. As in the case of land, a purely legalistic approach is not sufficient to fully appreciate the extent of the problem. For example, forests were an integral part of the rural economy as they provided the rural population with a significant share of the resources needed for breeding livestock, producing handicrafts, cooking and construction. ${ }^{19}$ Colonization led to disputes over the use of forests because the colonial 
authorities, interpreting the so-called 'Muslim' law, treated the forests as vacant land which under the regency of Algiers had belonged to the bey. The statute of 16 June 1851 enshrined this approach in law. ${ }^{20}$ The state then used the designation of vacant land to claim ownership of the forests and impose restrictions on or abolish the preexisting rights of use. However, this law remained inoperative until the forests were delimitated and a forest authority created. The creation of a forest administration extensive enough to modify the structures of rural life was a relatively slow, faltering process, occasionally subject to sudden progress. The Forestry Service, established in 1838 , still had only thirty-four members in $1843 .{ }^{21}$ It was pioneering in the sense that its members were committed to surveying Algeria's forest resources and to classifying them. The delimitation of these resources, a condition for the state's real ownership and hence intervention, did not begin before the 1850s. This enormous task - the total forest area was estimated at more than 2 million hectares - took several decades. By $1870,1,750,000$ hectares of forest were delineated and a further 550,000 hectares by 1880. By 1888 the demarcated forest area encompassed 3,247,692 hectares but more than 1 million hectares had not yet been delimited and therefore belonged to the state only in theory, as asserted by the law of $1851 .{ }^{22}$

This progress in forest delimitation after 1871 corresponds to what André Nouschi calls the 'triumph of the strongest men', ${ }^{23}$ a period in Algerian history when the forest management and surveillance apparatus grew noticeably stronger. From 1872 to 1886, the number of officers increased from 30 to 80 , the number of agents from 171 to 373 , and the number of native guards from 96 to 200 . The overall number of forestry personnel increased by 119 per cent over fourteen years. The increase was most marked in areas populated by cork oaks. In 1891, 275 forest rangers guarded 275,000 hectares of cork oak forests - one for every 1,000 hectares - whereas only 740 guarded the remaining 1,479,000 hectares - one for every 2,000 hectares. ${ }^{24}$ The colonial state prioritized the protection of the forests designated for colonization and invested not only in personnel but also infrastructure in doing so. More forest guard stations were constructed in the cork oak areas than elsewhere. With more stations, the guards were better placed to get to the scene of an incident quickly, so the service was more efficient overall. The construction of forest guard stations in the areas under the Forestry Service jurisdiction was therefore one of the key stages in the Service's evolution.

This development of the forestry system fostered rural discontent and banditry. Disputes over grazing, a central component of customary rights in forest areas, were a key stimulus for rural discontent. Under the regency of Algiers, the Beylik theoretically owned the forests but in practice did not restrict their use, with the minor exception of those needed for the naval industry. ${ }^{25}$ The colonial administration, along with new landowners and concessionaires, promoted a new approach which turned those lands into state, communal or private property. Customary rights were not, however, systematically suppressed. The colonial authorities could not simply abolish them, neither in law nor in practice. Successive laws reaffirmed and increasingly restricted the ability of the rural population to maintain and enforce their customary rights visà-vis the new landowners. This legislative process reached its height with the Forestry Law of 9 December 1885, in which article 1 affirmed the entitlement of forest owners to dispense with the existing rights of use. This law was the handiwork of the forestry 
lobby, which had the legislators' ear. The law put in place an industrial and commercial policy designed to make forest resources more profitable. 'Without the suspension of user rights and suppression of (cultivated) enclaves there can be no industrial exploitation of the forests, ${ }^{26}$ affirmed M. Étienne, a parliamentarian in Algeria and an owner of a great fortune in France. The forestry administration enforced these changes. The resulting restrictions on or suppression of customary rights were the cause of considerable conflict.

The number of crimes reported by the forest department increased sharply from 7,883 in $1881^{27}$ to 21,250 in $1902 .{ }^{28}$ The increase did not, however, accurately reflect the extent of criminality since, according to the general government, the forest department recorded only 10 per cent of offenses. ${ }^{29}$ The nature of the recorded infractions did not change much during those two decades. Two-thirds of the reports concerned illegal grazing, just over 10 per cent illicit clearing of crops or forest and the remainder tree felling. The fines for these offences were a significant source of profit for the forest owners (including individual proprietors). ${ }^{30}$ Conversely, they were a real burden for the rural populations living in or near the contested forests. 'It is in this way that the forestry administration keeps 800,000 natives down,' said the indignant senator Jules Ferry, 'making them kneel and tremble before it, and extracting from their poverty a heavy annual tribute which in 1884 amounted to 1,265,312 francs of financial penalties, fines, damages and expenses; in 1885, 1,321,307 francs; in 1888, 1,119,652 francs; in 1890, 1658958 Fr. ${ }^{31}$

In this context, certain forest areas became the theatre of a war of attrition, ${ }^{32}$ or, in E. P. Thompson's term, a 'forest war' ${ }^{33}$ Reports by forest agents and conservators complained about it repeatedly. For instance, in a note to the Governor General, the Directorate of Agriculture and Forestry referred to:

Devastation in the forests of the Azazga chiefdom. Grave and constant depredations, which the forestry service is powerless to repress. Some indigenous tribes are in a latent rebellion against the authorities. Those cutting down trees illegally in the State forests escape prosecution thanks to the complicity of the tribe chief who opposes both the administrative authorities and the forest department by inertia or by concealing the identity of the perpetrators. ${ }^{34}$

However, this conflict was not present on all of Algeria's territory, as it depended on the relations between the local population and the forest department in any given administrative district. From this point of view, the pace and pattern of the department's growth based on the areas' estimated wealth were decisive. In some parts of the Aures, forest rangers only established themselves from 1905 onwards and even then imperfectly and precariously. ${ }^{35}$

These conflicts were certainly connected with banditry, although the two phenomena were distinct and had different dynamics. A particularly interesting case is that of Ahmed Chabbi from the Beni Salah tribe, who was convicted of murdering a garde-champêtre ${ }^{36}$ guarding Amédée Rebattu's cork oak concession. The Beni Salah tribe, based in the east of Algeria in the Seybouse valley, suffered various forms of dispossession after the French conquest. Sequestration was imposed in 1852 
following a revolt ${ }^{37}$ and again in $1871^{38}$ and $1877^{39}$ as a result of forest fires deemed to be of criminal origin. Some the state's cork oak forests were allocated to very wealthy people as concessions. ${ }^{40}$ Amédée Rebattu managed a concession of 2,258 hectares. He hired a garde-champêtre and a native guard. In 1876 Ahmed Chabbi murdered the garde-champêtre. Even without knowing the precise circumstances of this murder, one can piece together a plausible picture from the facts gleaned from the archives. Concessionaires and forest owners were well organized in defending their interests and complained constantly about the preservation of customary rights and certain agricultural enclaves within their land, which they regarded as an unbearable constraint on their enjoyment of the property. Customary rights were the cause of conflict on the Beni Salah territory too after the sénatus-consulte was implemented in $1869 .{ }^{41}$ Branded as 'indigénophile' by its detractors, the sénatus-consulte constituted a stage in the delimitation and formalization of the property of the tribes. ${ }^{42}$ The question of customary rights, however, reappeared periodically through the actions of individual forest rangers. In the Souk Ahras province, just south of Beni Salah, a ranger connected to the concessionaire Lambert was accused of multiplying the number of reports for pasture. These reports reached an extravagant total of 88,555 francs in the space of a few months of verbalization..$^{43}$ There is no evidence that similar extravagance occurred on the property managed by Amédée Rebattu but, nevertheless, his complaints to the general government, in which he defended the need to expropriate the owners of enclaves, indicated that a conflict had taken place. Ahmed Chabbi murdered the garde-champêtre most likely because of this conflict. After his arrest, Chabbi managed to escape ${ }^{44}$ and he became a 'fearsome bandit' in the eyes of the French authorities. ${ }^{45}$

In the case of the Arezky's band, the establishment of the settlement village followed the construction of a forest ranger station for a ranger and an indigenous guard in an adjacent gourbi. ${ }^{46}$ This served to strengthen law enforcement, particularly with regard to the prohibition of charcoal manufacture. To produce charcoal, people collected wood from the forests and burned it under a layer of soil to starve it of oxygen. This became a commercial activity, and the colonial authorities sought to tax it by issuing manufacture licences. The colonists involved in this trade often sought increased state surveillance to enforce the prohibition. Illicit charcoal production became the subject of regular conflicts and occasional police reports (when the perpetrators were identifiable). Hadj Ali, one of the bandits close to Arezky, was wanted for the murder of a family of Italian charcoal makers in the Yakouren forest. Furthermore, with his band he ransomed 'especially forest rangers, who fear[ed] him very much' ${ }^{47}$ Hadj Ali's murder of the Italian charcoal makers can be interpreted as related to the conflict over customary rights in forests.

The process of colonization or, more precisely, of dispossession and privatization of the commons, was an essential condition for the emergence of banditry. The poet $\mathrm{Si}$ Mohand ou M'hand illustrates it with these verses:

'The rules are now perverted,

It is thus established

The vile men have taken the upper hand. 
All well-born men have taken to the forest

Braving the torments of adversity. ${ }^{48}$

\section{Banditry: A phenomenon of protest at the heart of rural society}

Banditry cannot be understood outside the social environment that gives rise to it and that accommodates it. The social environment is fundamental to the bandit's existence, and their resilience depends on understanding this fact. One should thus read banditry not as a marginal phenomenon ${ }^{49}$ but as one that emerged at the heart of rural societies. In this way, Eric Hobsbawm's notion of a 'social bandit' takes on full significance.

The administrative authorities in charge of keeping bandits in Algeria under surveillance and repressing them considered this anchoring the main danger. They believed the removal of this anchoring would put an end to banditry. Bouguerra ben Belkacem, the leader of a bandit group operating in the Philippeville region from 1875 to 1878 , was accused of thirteen murders and multiple thefts. At the trial, his judges claimed he was free to carry out these acts because during his four years as band leader there were no 'voices to denounce him' ${ }^{50}$ Similarly, the sub-prefect of Tizi-Ouzou considered Arezky el Bashir's band to be practically untouchable due to the support it had among the population, including among the Europeans 'forming pacts' with the band, 'by spirit of opposition' ${ }^{51}$ to the administration. These conflicts were fought over the 'monopoly on the legitimate use of physical force' ${ }^{52}$ by the competing authorities. The loose character of the colonial administrative network as well as its lack of political hegemony left a vacuum filled by bandits, who presented themselves as a rival political power. Faced with a colonial authority that was certainly powerful but distant from their daily life in the countryside, European settlers sometimes reached an agreement with bandits, whose authority was more immediate and visible. Bouzian el Kalaï, the famous bandit of the Oranais in the 1870s, counted among his supporters at least one European, Jean-Baptiste Graillat, who was accused of 'having furnished weapons, ammunition, instruments of crime, housing, a place of retreat, and a meeting place to an organized criminal association against persons and property'. ${ }^{53}$ Graillat's situation was representative of a section of the colonists. Tucked away on an isolated farm that he struggled to make prosperous, his relations with the local Algerians were out of reach of the central authorities' prying eyes. The transcript of his defence during his trial in 1876 clearly establishes the existence of relations between the colonists and the bandits. The latter visited Graillat at his home several times. Reports differed, however, as to the nature of their exchanges. Graillat denied that he sold arms to the bandits. By contrast, the testimony of Bouzian, of Bouzian's companion Si Kaddour and of Graillat's servant Antonin Macias affirmed that Graillat had sold arms. Even more compromisingly, the brigadier de gendarmerie Théry Charlemagne accused him of having knowingly given false information on at least two occasions. The transcript of the trial contains no evidence in favour of the accused. The close relations between bandits and colonial settlers were possible because the main seats of the colonial authorities were so far removed from where the settlers lived. The gendarmerie was several hours' ride from Graillat's home and his nearest European neighbour was five kilometres away. It seems 
likely that good relations were in the best interests of both the bandits and the settlers. The ammunition purchased by Bouzian and his companions was overpriced, which was understandable considering the relative precariousness of Graillat's situation. ${ }^{54}$ This type of relationship outside the framework of the 'colonizer' and the 'colonized' occurred regularly during the period when the three most famous bands of Algeria's colonial period were active. This contributes to making the phenomenon of banditry in a colonial situation more complex than it first appears.

Bandits adopted certain practical methods that traditionally belonged to a legitimately if not legally constituted political authority. For instance, they collected taxes from the local population: 'the bandits demanded money from all the people who properly served the administration and who would not submit to them' ${ }^{55}$ Arezky was even accused of 'levying fees on market routes' ${ }^{56}$ Bouzian el Kalaï devised his own particular form of taxation by stealing directly from the caild (a village chief nominated by the colonial administrator) and the douar tax collector Ouled Saï. The caïd was robbed on his way to Mascara (the district capital), while he was transporting the taxes of his constituents. ${ }^{57}$ Besides capturing the revenues collected by the legally constituted authority, the bandits also sought to assert their charismatic authority. They sometimes organized large festivals on religious occasions. These expensive festivals, where guests often numbered in their hundreds, were an opportunity to demonstrate the bandits' gratitude to their social environment but also to emphasize the people's obligations and loyalty to them. For example, Arezky el Bashir organized a diffa (feast) to celebrate his son's circumcision. ${ }^{58}$ Mohammed Saïd ou Abdoun too organized a diffa which one thousand guests attended. Their ability to organize such events without the knowledge - or at least without the interference - of the authorities reveals how bandits were anchored in and respected by the local community. The bandits' centrality in social life is also attested by the fact that people continued to take care of their land and cattle even when they were away from the village. In this way, the property belonging to Abdoun, who was at one time a companion of Arezky el Bashir, was 'managed and administered by relatives' ${ }^{59}$ The shared management of their land and livestock enabled these men to generate the income needed to procure services. The nicknames that journalists or administrators gave Arezky, such as 'the king of the forest' ${ }^{60}$ or 'the chief of the Sebaou' ${ }^{\prime 61}$ were not simply expressions of an Orientalist imagination but also an acknowledgment of the political reality.

This political power expressed itself by the use of violence. An analysis of its targets allows us to interpret some of the bandits' motivations ${ }^{62}$ :

The data in Figure 6.1 are an imperfect reflection of the bands' activities. Thefts from rural Algerians are under-represented because they were less likely to result in conviction. The first council of war of the Oran division did not take into account the innumerable 'rapine acts committed daily to support the existence [that the band of Homati] led'. ${ }^{63}$ Despite being under-represented in the official figures, ordinary Algerians were still the bandits' most frequent target. These figures reveal the complexity of the banditry phenomenon. The wealth of the Algerian victims was regularly cited as the crime motive, revealing the socio-economic hierarchy within the colonized society. European victims were less numerous but still significant - 17 per cent of all convictions. Crimes against Europeans were often perpetrated by wellestablished bands with several months or years of experience, who were consequently 


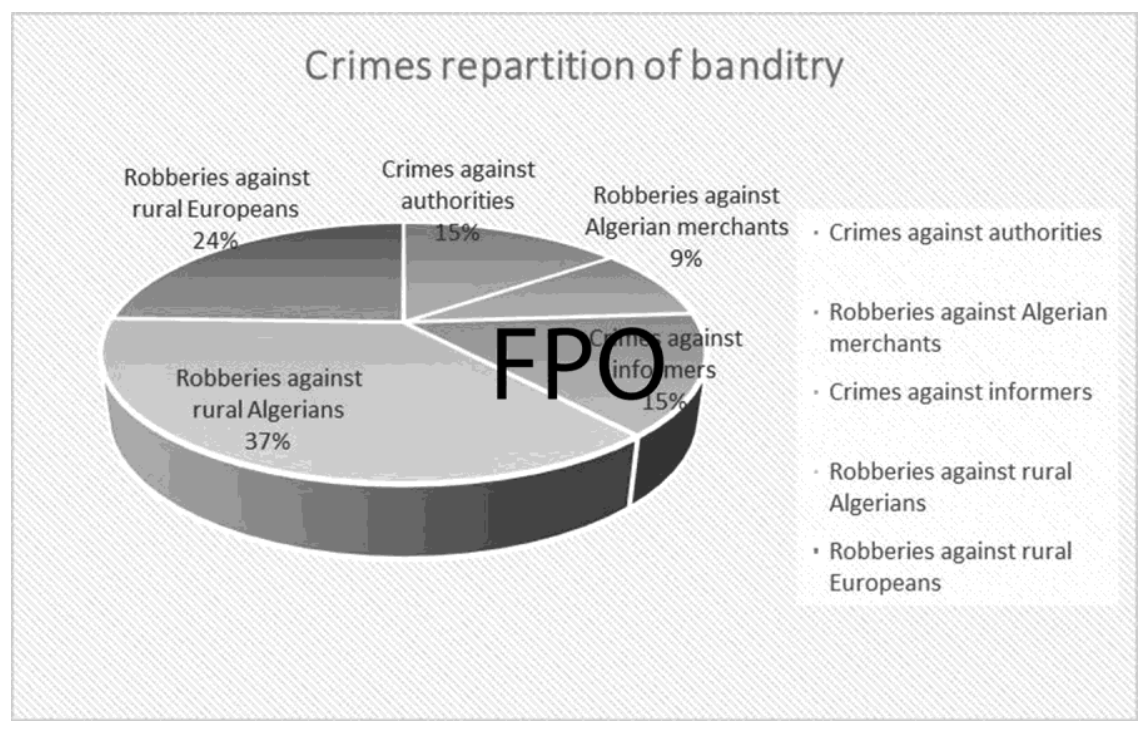

Figure 6.1 Targets of violent crime in banditry-related convictions (Algeria, 1871-1914)

more confident in their actions. However, some of the better-known bands, such as Arezky el Bashir's band, managed to consistently avoid this kind of confrontation. Bashir only targeted the Algerian representatives of the colonial authorities when seeking vindication. Attacks on merchants, who were often portrayed as Kabyle or Jewish, made up 10 per cent of the banditry-related crimes that resulted in conviction. The bandits thus understood and used social stratification to get rich quickly. The sums extorted from merchants on market routes were large relative to rural people's other sources of income. The evidence suggests that bandits worked almost exclusively as labourers, farmers or charcoal-burners. The term 'farmer' refers to peasants managing their own land. The farmers' standard of living is difficult to quantify, but labourers and charcoal-burners were undoubtedly poorly paid. A labourer earned on average 1 to 1.50 francs per day. In the case of the Beni Salah band, convicted in 1883 by the Assize Court of Bone, three of their robberies had reportedly yielded 1,030 francs, 725 francs and 5,000 francs. ${ }^{64}$ These were extraordinary sums compared to the labourers' daily income. Finally, the specific dynamics of banditry help explain the last two groups targeted by bandits. The first consists of members of the colonial administration in charge of gathering intelligence on bandits or actively suppressing them. These were the Algerian agents of the colonial administration (amins, spahis). Occasionally, however, a European gendarme or forest ranger was found among the targets. The second group comprised Algerians who informed on the bandits, who account for 15 per cent of the convictions handed down by the assize courts or councils of war. The bandits sought to incite fear in those who might be tempted to give information to the authorities. 
Theatricality was part of the political dimension of the bandits' violent acts. Bouzian el Kalai first became a bandit when he refused to pay his taxes, the main manifestation of state authority. The caild who sought to impose the tax upon him was slapped and then ridiculed. The bandits then completed the caild's humiliation by stripping him and leaving him naked some distance away from his douar. ${ }^{65}$ The purpose was to undermine his authority and manliness by means of symbolic violence, a strategy that bandits used frequently. Representatives of the authorities would also often fall victim to these measures, as in the case of a forest ranger abducted and 'put in a state of complete nudity'. ${ }^{66}$ Showing the vulnerability of official authority in this way helped establish the authority of the bandits in counterpoint. Theatricality was also a feature of the great diffas the bandits organized. At one of them, in a symbolic battle, 'the guests made tricks about the French authorities'. The liveliest member of the band snuck out past their comrades, then came back in, shouting: 'The administrator! The gendarmes! And sat back to their place having provoked peals of laughter and lazzi from the few hundred natives who surrounded them.' ${ }^{67}$ This spectacle of the oppressed, where statements usually kept private erupted into the public sphere, was deeply disturbing to the colonial authorities, who never succeeded in eradicating this kind of behaviour. ${ }^{68}$

\section{Eradicating banditry: The limits of the colonial state}

In addition to the scenes already described, the very existence of bandits as a rival political power served to deride the colonial authorities. Administrators' reports constantly expressed an association between this rival authority and the apprehension of an imminent revolt. Camille Sabatier, who successively served as a judge in Blida, an administrator of a commune mixte in Kabylie, then an MP for Oran and finally a commissioner of the general government on prison matters, ${ }^{69}$ clearly expressed this opinion:

It is among the gangs of thieves and criminals that they recruited the most vigorous agents of the insurrections; and it is also with the resurgence of crimes and offenses against individuals that the beginnings of an insurrectionary period can be detected. ${ }^{70}$

Public speeches on 'insecurity' thus not only include a sharp condemnation of attacks on property ${ }^{71}$ but also a politicized fear that the situation would degenerate into insurrection. The colonial authorities sought to crush banditry precisely because they recognized it was the earliest stage in the evolution of an insurrection. But they faced a dilemma: how could the colonial state exert repressive force without experiencing a failure that would in fact reveal its weaknesses? Despite their best efforts, the colonial authorities regularly failed to crush banditry. The unequal balance of power frequently compelled bandits to evade the colonial authorities rather than seek open confrontation with a larger and better-equipped force. When seeking to evade the gendarme patrols, the spahis or the army, bandits made use of their own intelligence network. The colonial officials lacked access to this subaltern information network 
and complained constantly that they were thwarted in their efforts to intervene. 'The natives do not seem to be loyal to us, and the information I receive does not seem to me sufficiently clear to enable us to act effectively, ${ }^{72}$ reported the administrator of the commune mixte of Azazga before the beginning of a military campaign to eradicate banditry in Kabylia. The French colonial officers did not fully trust their own indigenous agents. Compulsory transfers, revocations or even trials for cooperation with bandits happened regularly. Following the assault on two gendarmes in the Blida area in 1906, the city police chief reported that he was 'unable to obtain information, including from the indigenous personnel' ${ }^{73}$ In this way bandits managed to avoid capture and punishment, sometimes for many years. In the defined corpus, it took in average two years and eight months to suppress a bandit - measured from the time of his first infraction to his effective arrest - but bandits were at large from anywhere between a few days and nine years.

The colonial authorities took two distinct but complementary tactics in liquidating bandit bands. First, they sought to isolate the bandits socially. There were special surveillance procedures for targeting the milieu presumed to be supporting bandits. Through these non-judicial procedures, the administrator of a commune mixte could request the resettlement of these people to a new, distant place of residence. ${ }^{74}$ The colonial administration used this procedure consistently in banditry cases. The administrator of the commune mixte of Zerizer used this weapon in 1881 in order to eradicate the bandits who sowed 'terror in this country'. ${ }^{75} \mathrm{He}$ deported seventyone people suspected of supporting a band, only four of whom were convicted of banditry by the Assize Court in Bone. The number of bandits among the deportees gives an indication of how well embedded they were in society. The deportees experienced a sad and constrained exile as well as terrible poverty and few means of escaping from it. Such conditions were often fatal; at least sixteen of the seventy-one people deported by the Zerizer official did not survive their deportation. ${ }^{76}$ While trying to deprive the bandits of support and access to intelligence, the colonial administration also sought to obtain information. They routinely offered bounties for the denunciation or capture of bandits, with the size of the reward increasing gradually. The colonial authorities took advantage of the population's general poverty to lure in informants. In the 1870 s, 1,000 francs were promised to 'the native or the detachment ${ }^{17}$ who will succeed in capturing the bandit Bouziane El Kalaï. The bounties were relatively effective so long as the informants remained protected, but the amounts grew steadily over time precisely because the informants' safety could not be guaranteed. ${ }^{78}$

In addition to social isolation, military intervention was the second major tool of repression. Military campaigns were rare but revealed the colonial administration's political fear of banditry. Of the nineteen bands mentioned above, four were liquidated through military intervention. In two cases it took multiple campaigns for the authorities to achieve their objectives. The first military campaign against the Arezky band failed partly because of its lack of understanding of the social environment as well as geographical conditions. The state only resorted to military campaigns in cases when the civil authorities were unable to eradicate a given band. Nonetheless, social isolation was still a necessary first step to any successful military 
intervention. The colonial military force was much greater than that of any bandit group. The military manoeuvers involved sealing off a territory and then scouring it thoroughly. Stations were established at intersections and passes and travel routes were restricted. Between these stations, patrols or mobile groups coordinated with each other to prevent bandits from moving between territories. These operations employed military personnel as well as the civilian population forced to serve under the supervision of the administrator or sub-prefect in charge. In November 1893, 310 men were mobilized in the military campaign in Kabylie, half of them tirailleurs. The authorities preferred to deploy Senegalese riflemen recruited in French West Africa, relying on their reputation for violence and cruelty in order to incite fear among the rural population. ${ }^{79}$

The troops lived off the local population. The sub-prefect of Tizi Ouzou defended this approach as follows:

Although I am in principle an enemy of collective responsibility, since it is undeniable that the natives, whether through fear or for any other reason, give their support to the bandits, the troops employed in the repression of banditry might live off the douars during the occupation, with the amounts to be requisitioned to be determined in advance. ${ }^{80}$

It was therefore also a way of making rural people pay for the support they have given to the bandits. Feeding a military unit of several dozen men (several hundred were distributed among a number of douars) was a considerable economic burden for the local population. The use of the term 'collective responsibility' by the sub-prefect of Tizi-Ouzou was not innocent. It echoed the colonial debates of the time and the prevailing opinion that colonized people should not benefit from the principle of individuality of punishment. Although during other campaigns the troops were supposed to cover their own costs, the existence of written complaints by rural people as well as the authorities' repeated insistence on the rule indicates that the army often did not follow it in practice. In addition to imposing a financial burden, the colonial administration pursued a policy of terror towards the rural population during these military campaigns. Complaints from the rural population testify to the humiliations and violence they suffered. Complaints relating to several incidents were preserved in the archives despite the many obstacles to their redress. In a 1904 case of brigandage that led to investigations in the Hessounat douar, the indigenous deputy complained to the Justice Minister about the violence he had suffered and his wives' humiliation at being made to strip naked while the security forces searched their house. ${ }^{81}$ The purpose of the campaigns was not only to defeat the bandits but also to impose political control over the local population in the never-ending battles between the authorities and the bandits over legitimacy. These campaigns, coupled with the social isolation of bandits, ultimately succeeded in breaking up the bands they targeted. Nevertheless, the phenomenon of banditry reappeared regularly in different regions of Algeria, even experiencing something of a revival during the First World War. ${ }^{82}$ 


\section{Conclusion}

The first salvo of critiques against Hobsbawm focused on his use of oral or literary sources to document the history of banditry and not the history of its representations. This critique is now generally accepted, including by the pioneer historian himself..$^{83}$ Does this mean that the notion of social banditry is no longer meaningful? The romantic view of banditry must be treated sceptically or interpreted as a historical representation in itself. Yet social banditry remains a relevant concept when understood as a phenomenon that was not marginal but central to the societies in which it emerged. To shed light on the reasons behind the emergence of banditry, attention should be paid to large-scale social transformations within rural societies. Understanding dispossession on a global as well as local scale is central to shedding light on the appearance, spread and life cycle of banditry. Dispossession was part of the reason why bandits received support in their social environment. Other factors including family ties, relationships between or within tribes, the values of the socalled 'traditional societies' - were also relevant but probably less so. The colonial state nevertheless remained outside the bounds of these relations and thus struggled to understand the phenomenon of banditry and bring it under control. Fearful of potential risks to its authority, the colonial administration tended to overestimate the numerical scale, if not the political significance, of banditry. There were two main reasons behind the authorities' exaggeration of the problem. First, the prospect of an imminent insurrection was a source of constant preoccupation for the colonial administration. Second, the exaggeration of the phenomenon served to legitimize the expansion of law enforcement mechanisms and weld colonial public opinion around the government by stirring up fears of the 'native bandit'. The latter function of state responses to banditry should not be underestimated as case studies on Algerian banditry tend to show a complex phenomenon regularly transgressing the imported categories of the 'colonized' and the 'colonizers'. In any case, the colonial state's different responses to banditry stemmed from the basic aim of annihilating this form of resistance to the state authority. Ironically, the history of the colonial administration's struggle with banditry reveals important limits of its power. 